\title{
Exploring some marketing practices in management consulting firms: evidence from small service firms in Italy
}

\author{
Linda Gabbianelli and Tonino Pencarelli \\ Department of Economics, Society and Politics, \\ Università degli Studi di Urbino Carlo Bo, Urbino, Italy
}

Exploring

marketing

practices

\begin{abstract}
Purpose - The purpose of the paper is to investigate the marketing and communication activities carried out by small management consulting firms and how they relate to customers.

Design/methodology/approach - After the framing of the literature on the subject, the study is based on the results of a survey carried out through an online questionnaire. The sample under investigation is represented by 914 small consulting firms located in central Italy.

Findings - Results show that half of the sample carried out marketing and communication activities, mainly through the website and social media, while others participating in events as speakers at conferences. It also emerges that management consulting firms carry out activities aimed at maintaining relationship with customers even if they do not invest time in market research in order to find potential and new clients.

Practical implications - The study suggests that management consulting firms should adopt a systematic and strategic approach to communication and should develop a complete and integrated digital communication strategy, as well as to rethink the consulting business model.

Originality/value - There are no previous studies that provide insight into the everyday practice of marketing and communication of small management consulting services in today's dynamic and changing economic environment.
\end{abstract}

Keywords Management consulting firms, Communication, Service marketing, Relationship, Small firms

Paper type Research paper

\section{Introduction}

Professional service firms are at the extreme end of the intangibility range (Amonini et al., 2010) because their main input and output is knowledge (von Nordenflycht, 2010). This knowledge is embedded in specialized services such as consultancy, usually developed and delivered by highly skilled employees.

Previous studies have long appreciated that there are different "types," "forms" or "modes" of knowledge, and that these are associated with different activities. However, in order to clarify and avoid to deal these firms as a homogeneous grouping, Muller and Zenker (2001) distinguish knowledge-intensive business services into two main categories: (1) traditional professional service firms and (2) new technology-based (e.g. such as R\&D services and computer services) service firms.

Professional service firms are typical service firm and have the following characteristics: are knowledge intensive, require low capital investment and provide customized offerings (Miles, 1993) such as law, accounting and management consulting (von Nordenflycht, 2010).

(C) Linda Gabbianelli and Tonino Pencarelli. Published by Emerald Publishing Limited. This article is published under the Creative Commons Attribution (CC BY 4.0) licence. Anyone may reproduce, distribute, translate and create derivative works of this article (for both commercial and non-commercial purposes), subject to full attribution to the original publication and authors. The full terms of this licence

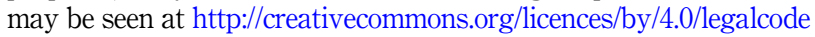

Received 31 December 2019 Revised 4 May 2020 2 July 2020

Accepted 27 July 2020 
The management consulting firm is commonly studied as the archetype of a knowledgeintensive firm (Alvesson, 1995; Crucini, 2002; Heller, 2002; Werr, 2002) so much so that consultants are aware that their core product is knowledge itself (Salvary, 1999). The literature related to the definition of management consulting activity is wide (Whittle, 2006) and heterogeneous (Wittle, 2006; Barcus and Wilkinson, 1995; Greiner and Metzger, 1983; Kass and Weidner, 2002; Kubr, 2002; Steele, 1975; Ciampi, 2014). In general, the management consulting is defined as an independent professional advisory service assisting managers and organizations to achieve organizational purposes and objectives by solving management and business problems, identifying and seizing new opportunities, enhancing learning and implementing changes (Kubr, 2002).

Management consulting firms face challenges when promoting, protecting and leveraging their intangible resources.

On the one hand, consumers who cannot rely on previous experience for making an informed decision typically depend instead on a firm's reputation (Fombrun and Shanley, 1990) [1].

On the other hand, consultants feel uneasy about selling their services: they think that it is unprofessional and beneath their dignity. Marketing is often thought as a set of activities, tools or techniques, which cost time and money and which many consultants would prefer to avoid. This reluctance is also due to the fact that many consultants are poor in marketing, and, if they have to market, they do it with little enthusiasm.

Kotler and Connor (1977) define marketing in professional services as "organized activities and programs that are designed to retain present clients and attract new clients by sensing, serving, and satisfying their needs through the delivery of appropriate services on a paid basis in a manner consistent with credible professional goals and norms."

Marketing is needed to establish and maintain an effective consultant-client relationship; it does not stop when a sale is made, and the consultant continues to market after the contract has been signed - during the consulting process and even after the end of the consulting process.

As the marketing of consulting is strongly affected by the "intangibility" of services and consumers feel uncertain about the quality of an offer due to the lack of tangible attributes, the consultant can only sell a promise of a service that will meet the client's needs and solve his problems.

Thus, the consultant has to convince the client that, from the strictly technical point of view, he has all the technical knowledge, know-how and information needed to deal with the client's technical problem.

In addition, consulting is mostly based on human relationship, as Maister (1982) argued that professional services usually involved a high degree of interaction with the client. It emerges that the marketing of consulting services deals with two dimensions of the consulting approach: the human dimension (the relationship between the consultant and the client) and the technical dimension (the technical know-how needed to solve the client's specific business problem).

Relationship building, close collaboration, teamwork and partnership are emphasized in management consulting, and it has become common to speak of close client collaboration as a key factor for creating value (Carucci and Tetenbaum, 2000).

Service research has indicated that the co-creation of value as a social accomplishment only occurs when parties influence each other in some kind of joint sphere (Prahalad and Ramaswamy, 2004; Vargo and Lusch, 2008; Lambert and Enz, 2012; Grönroos and Voima, 2012) [2].

Svensson (2010) suggests that consultant-client interactions that lead to value creation are not only practical, but they also comprise mental, emotional and spiritual elements.

Adopting the service-dominant logic approach, a company should customize its commercial proposals by recognizing that clients are always value producers and should 
enhance the customers' involvement to better fit their needs (Vargo and Lusch, 2004) where clients are viewed as value-creation partners. As the service-dominant logic implies that suppliers have to support the clients' value-creating process, it extends the crucial role of marketing to other areas of the company: all employees are identified as service providers, with the ultimate goal of satisfying the customer (Vargo and Lusch, 2004; Ballantyne and Varey, 2008). Grönroos and Ravald (2011) show the implication of the service-dominant logic for marketing.

Referring to the value-creation process through the experience logic approach (Pencarelli and Forlani, 2018), the customer, actively contributing to the co-production of the experience, co-creates contextual value-in-use before, during and after the experience. In this context, the value is experiential and qualified as a value of exchange, possession and used both during interactions with suppliers and even outside the boundaries of the relationship with them, involving wide networks of actors.

In the management consulting context, the consultant provides value propositions in order to optimize the customer experience before, during and after the consulting process.

A wide range of techniques are available to management consultants for building up their professional reputation and image or for positioning their practice in the client's mind. Their purpose is not to sell individual assignments, but to get potential clients informed about and interested in the consulting firm and its products and to create opportunities for new contacts.

However, in practice, very seldom firms have their own marketing departments or a specific employee responsible for marketing (Jaafar et al., 2008). The main task of the person responsible for marketing is marketing communication, which includes advertising, promotional activities and public relations. However, a few firms consider communication elements to be very important and consequently the customer orientation is low (Jaafar et al., 2008).

The majority of management consulting firms in Italy operate on a small-scale basis and do not have marketing departments.

In particular, the management consulting sector in Italy is made up of almost 23,000 firms, which generate a turnover of around 4.5 billion euros and employ 45,000 employees (Confindustria Assoconsult, 2019). It is a highly fragmented sector, with a polarized structure between a very small number of large groups $(0.2 \%)$ and many small $(12 \%)$ and micro $(86 \%)$ management consulting firms. This polarization reflects the economic and productive structure of the Italian territory, articulated on the basis of SMEs and a relatively small number of large economic groups of international relevance.

While the literature on service firms has put a lot of emphasis on their structural characteristics, geographical location and innovativeness, little attention has been paid to the day-by-day management of these companies, including marketing (Muller and Doloreux, 2009; Coviello et al., 2006).

Based on the features of management consulting firms (facing short deadline, typically small-sized, with a lack of dedicated human resources with marketing expertise and the reluctance to invest time to marketing), together with a lack of literature focused on small service firms, the paper contributes to fill this gap by analyzing the marketing practices of 914 small management consulting firms in Italy.

Referring to this objective, our study tries to answer the following research questions:

$R Q 1$. Do management of small consulting firms carry out marketing activities? If not, why?

RQ2. Among those who practice marketing activities, what kind of communication do management consulting firms carry out?

RQ3. How do management consulting firms relate to customers in terms of building and maintaining the relationship?
Exploring marketing practices 
To answer these research questions, a review of major studies on marketing of management consulting firms is presented (paragraph 2).

Paragraph 3 shows the methodology followed for the empirical survey conducted by sending a questionnaire to 18.342 management consulting firms. The findings are illustrated in paragraph 4. Paragraph 5 concerns the discussion of results, while paragraph 6 concludes the paper providing managerial implications and showing limits together with future directions.

\section{Marketing of management consulting firms}

In the past, the marketing of the consulting profession had been denounced, then debated and ultimately declared necessary (Barr and McNeilly, 2003). It was only in the early 1970s that the marketing of services emerged as a separate area of marketing with concepts and models of its own to accommodate the typical characteristics of services (Gummeson and Grönroos, 2012).

Marketing, far from being a neglected function in managing professional services firms, is now recognized as one of the most important functions for helping consultants to meet the unprecedented challenges faced by them (Kotler and Connor, 1977).

Service industries, in particular consulting firms, have historically considered marketing as a luxury rather than a critical part of the business mix. For this reason, service organizations have been slow to adopt marketing concepts and techniques (Nagdeman, 2009).

Management consulting firms face short deadlines, are typically small, often lack marketing expertise (particularly in smaller firms) and have been reluctant to devote time to marketing and to promote their services: such activities are seen to reduce billable hours (Ellis and Mosher, 1993; Herbig and Milewicz, 1993; Kotler et al., 2002).

Correspondingly, the service value proposition is difficult for clients to evaluate even after receiving the service (Macintosh, 2009).

Sweeney et al. (2011) believe that understanding how professional service firms approach their marketing activity is important for many reasons. Firstly, the sector is a significant component of the Western economies. Secondly, the sector has expanded rapidly. Thirdly, there are industry characteristics influencing marketing practice which represents challenges for practitioners. Lastly, whilst the nature of consulting service is generally highly specialized or technical, the process in which the service is delivered relies heavily on human relationship factors.

Kotler et al. (2002) and Gummesson (1979) argue that all professional service firms practice marketing in some form, whether or not the activity is called as such.

Familiarity with marketing trends and methodologies can both improve decision-making process regarding the choice of marketing mode and style best suited to management consulting service businesses and help to identify client needs and enhance the delivery of value adding services.

Enerson et al. (2016) suggest that current and future marketing directions will affect the way that the professional service marketing is formulated and implemented. The authors believe that in the professional environment, service organizations that have a clear marketing direction will have more chance of succeeding.

Reid (2008) observes that both small and larger service firms focus on both service market development and acquisition of new clients, with larger organizations placing greater emphasis on the client retention and the development of sustainable relationships.

Concerning professional service firms, Gummesson (1979) identified possible activities within the area of marketing, concentrating on promotional activities, that is, the various ways of communicating with and influencing the market such as telephone directories, direct mails, conferences, symposiums, seminars organized by the service firm, participation in conferences, participation as expert, publication of articles, books and annual reports, participation in professional and social activities and joining network organizations such as business clubs, industry associations and sport clubs. 
The role of digital marketing has generated some relevant challenges for management consulting firms such as the explosion of data (big data) and social media, the proliferation of channels and how to manage most of the online communication channels (Ramsey and McCole, 2005).

It emerged that it is an increasingly sophisticated consumer who can make more advanced demands with more readily available information (Karam, 2003).

The Internet can provide to potential consumers the access to information even if the actual transaction will take place offline (Langrosen, 2005), and in the 21st century, this information is accessible literally at one's fingertips, via their smartphones.

However, through the digital marketing, consulting firms are able to know how customers collect information, use that information and how that information is used in their decisionmaking process, shopping behavior and post-purchase behavior (Mayzlin and Yoganarasinhan, 2012; Onishi and Manchanda, 2012). In response, despite the growth in consumer demand for services, there has not been an adequate increase in the development of marketing skills in service industries, particularly in professional services (Ettenson and Turner, 1997).

Coupey (2001) states that the Internet improves not only the efficiency of the development and implementation of marketing activities but also the content and activities. To remain competitive in global and local markets, Internet-enabled capabilities are therefore believed to be imperative.

Essentially, by advertising and providing services on the Internet, firms generally offer customers value through the firms' presence and the means to develop long-term, one-on-one relationships with the firm (Mathur et al., 1998).

However, as services cannot be experienced before purchase and service firms are demonstrated to significantly rely on word-of-mouth to attract new clients and improve customers' loyalty, it is surprising the scarce attention given on the usage of social media marketing (Buratti et al., 2018). By generating and influencing conversations in communities and networks, in fact, social media tools have proved to influence word-of-mouth communication (Trusov et al., 2009; Huotari et al., 2015).

There also emerged the relevance for service firms to develop a website (Roxas et al., 2000) to attract new clients, as a first step to enter into a business relationship, to portray credibility and technological advancement and to promote the firm's image. Although a website cannot substitute the power of personal interaction with clients, it can initiate and sustain customer relationships, as well as reinforce commitment to clients. In summary, given the situational challenges, the difficulties in marketing credence services such as professional service firms and the task of integrating technical expertise with a relational approach, it may be interesting to investigate how small management consulting firms practice marketing and market their services.

However, it should be noted that relatively little literature on marketing of management consulting firms exists (Barr and McNeilly, 2003; Enerson et al., 2016; Cerruti et al., 2019). While a great of deal has been written regarding what firms could and should be doing, there is little literature that reports what they are doing (Barr and McNeilly, 2003). In terms of dimension and geographical perspective, literature is scarce regarding studies that focus on small management consulting firms in the Italian context.

Table 1 summarizes the main studies on marketing management consulting firms in the last 20 years: it shows that most of articles adopted a qualitative method through indepth interviews. Geographically, there was no data on marketing management consulting either in the European context or the Italian one. In addition, the unit of analysis is wide and fragmented, from general professional service firms to engineering, accounting, architectural and legal firms. Few researches are exclusively focused on management consulting firms. 
TQM

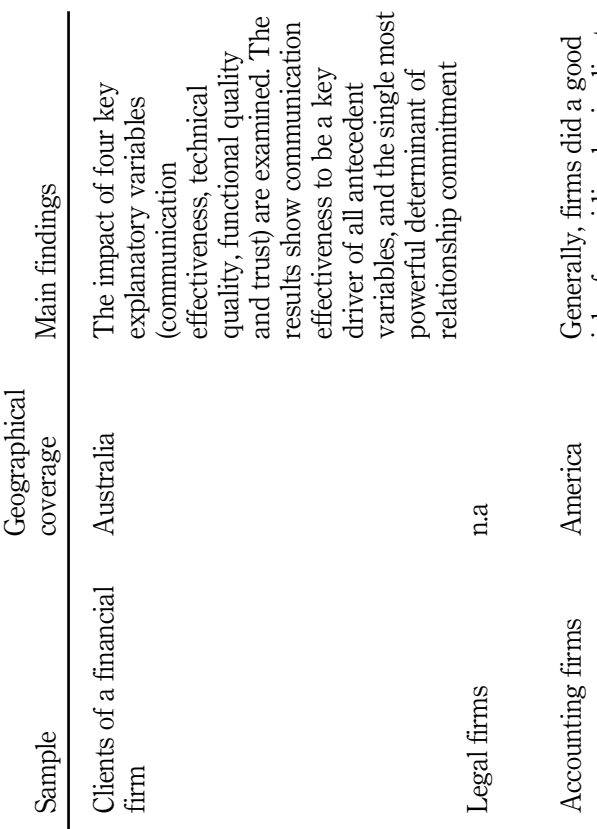

Table 1.

Summary of previous studies on relationship marketing in management consulting firms (in the last 20 years)

墨

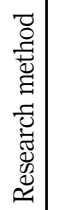

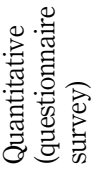

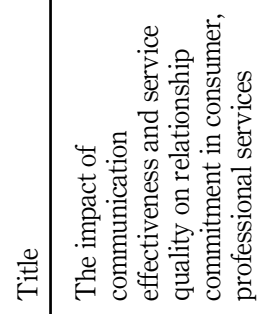

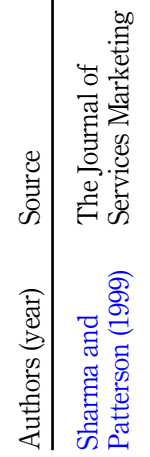
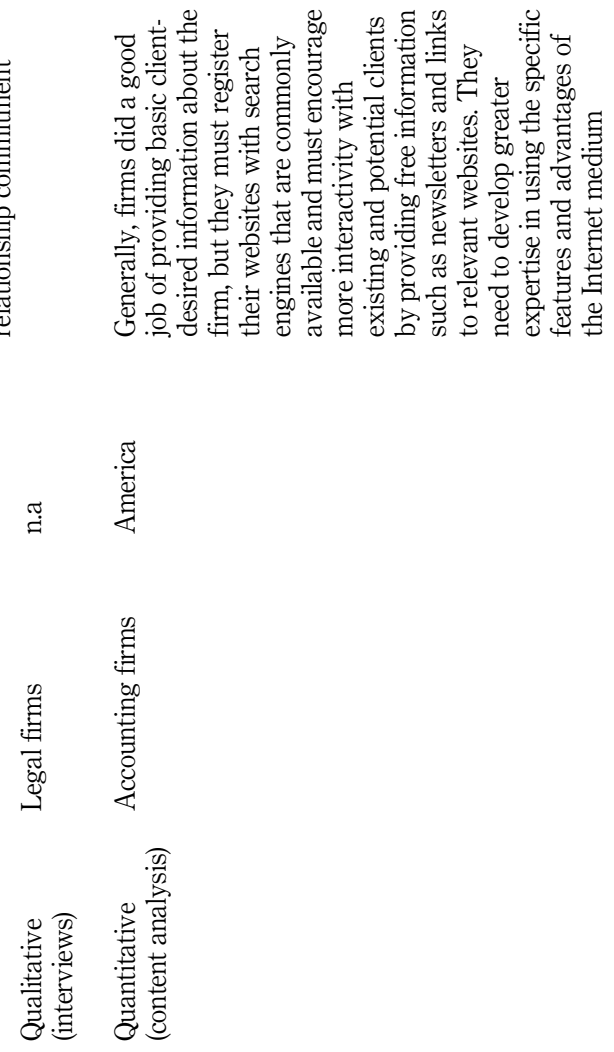

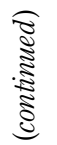

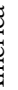

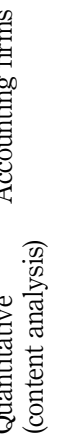

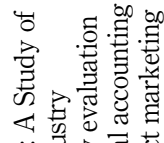

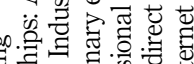

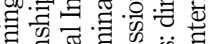

.0

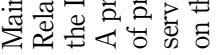

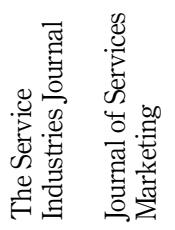

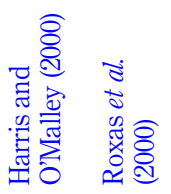




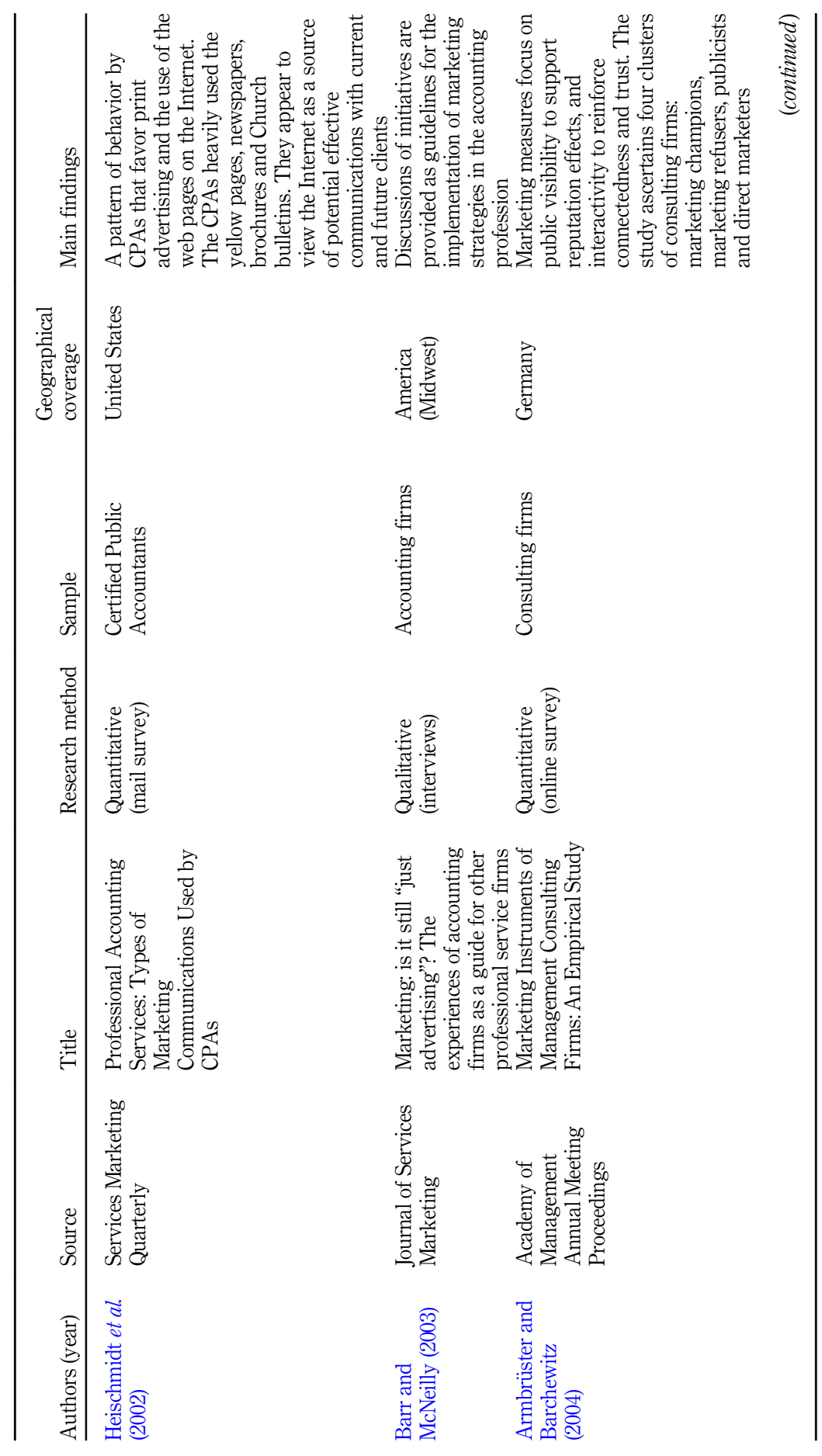

Exploring marketing practices

Table 1. 
TQM

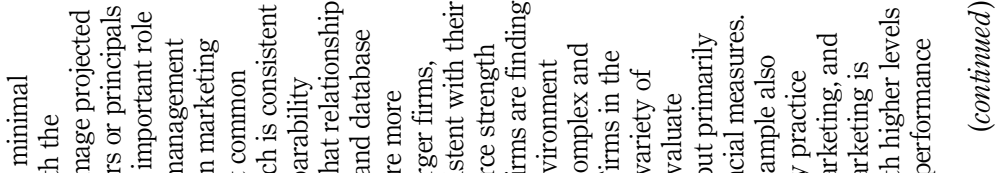

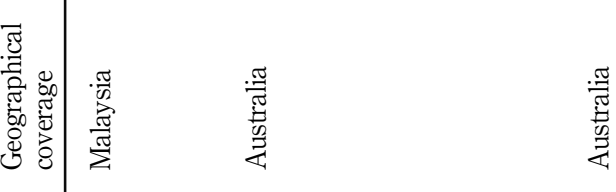

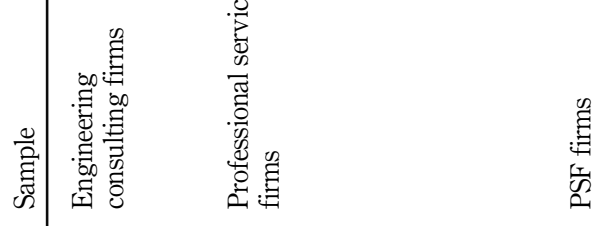

黑

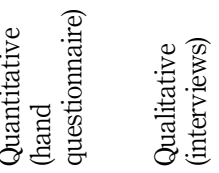

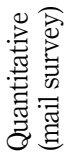

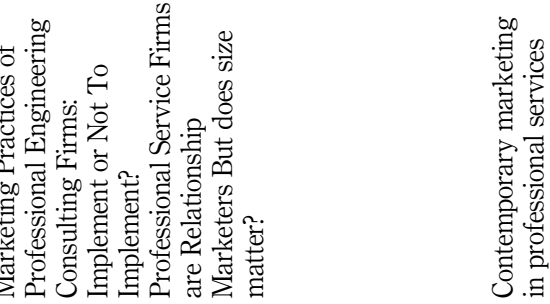

Table 1.

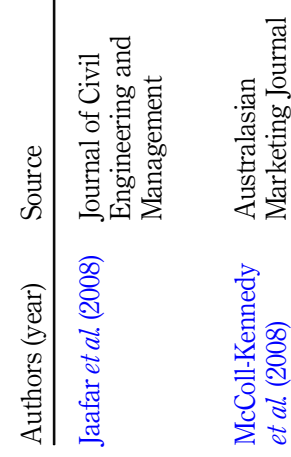

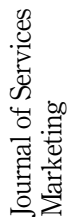

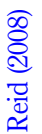




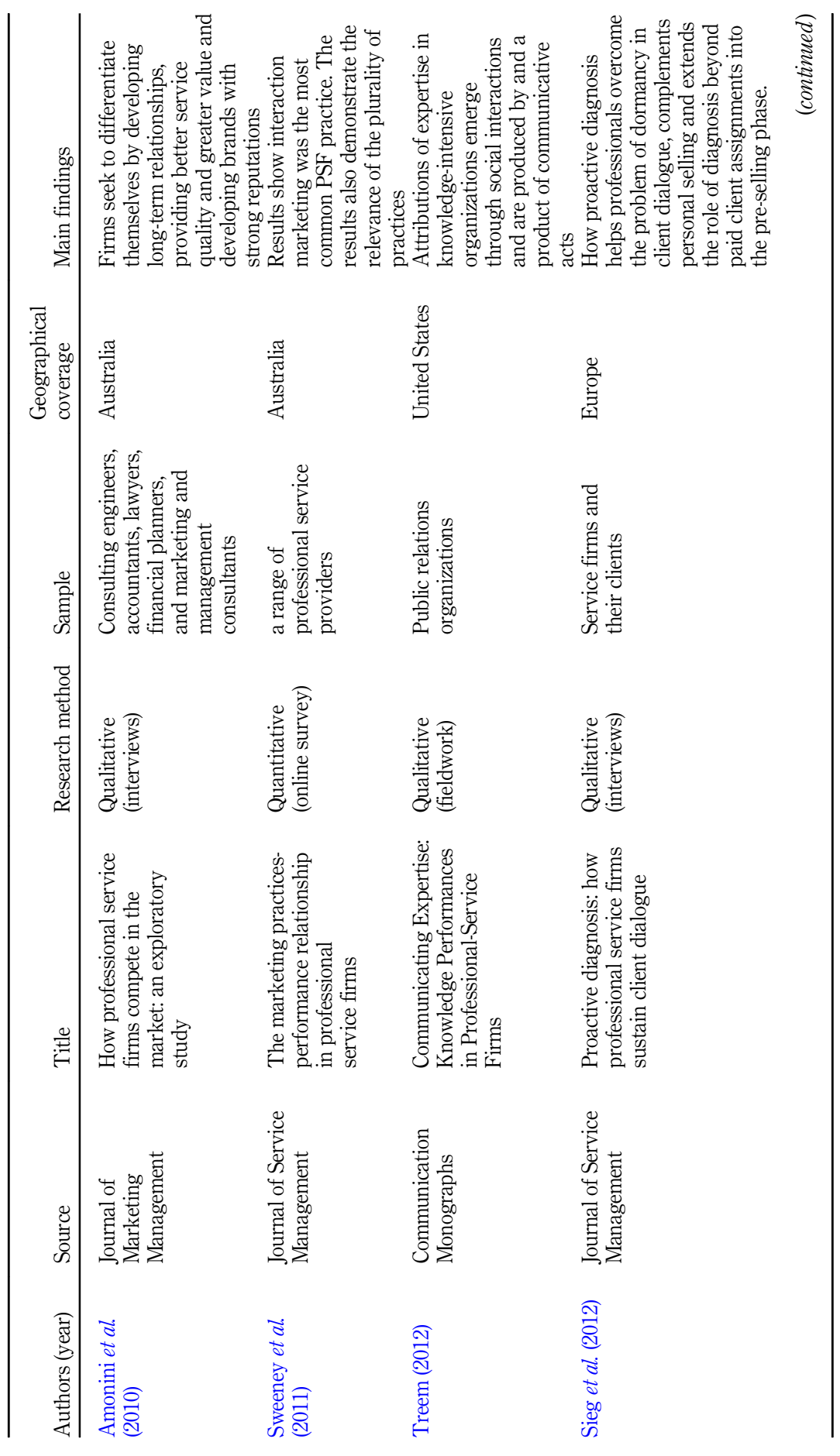

Exploring marketing practices

Table 1. 

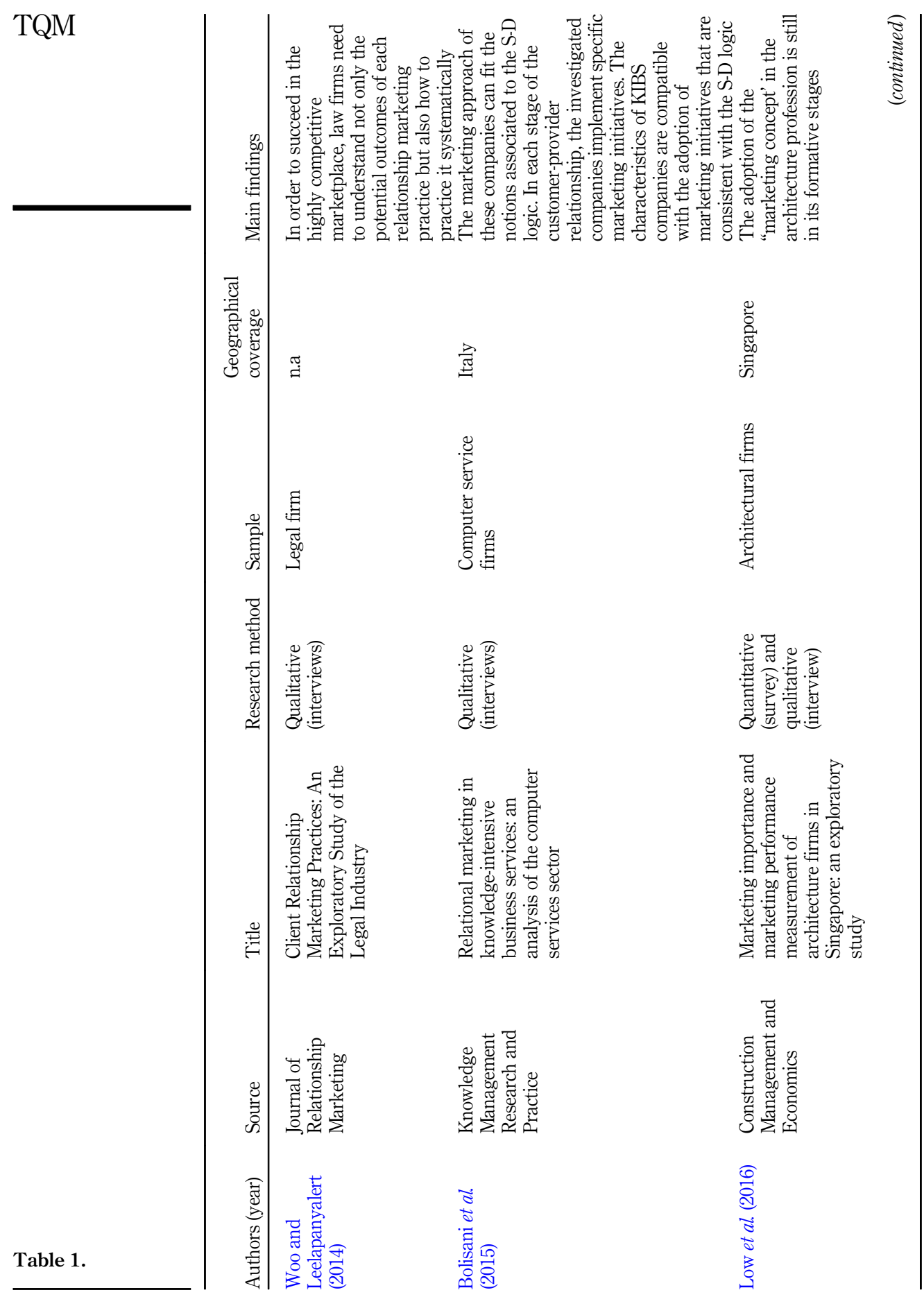

Table 1. 


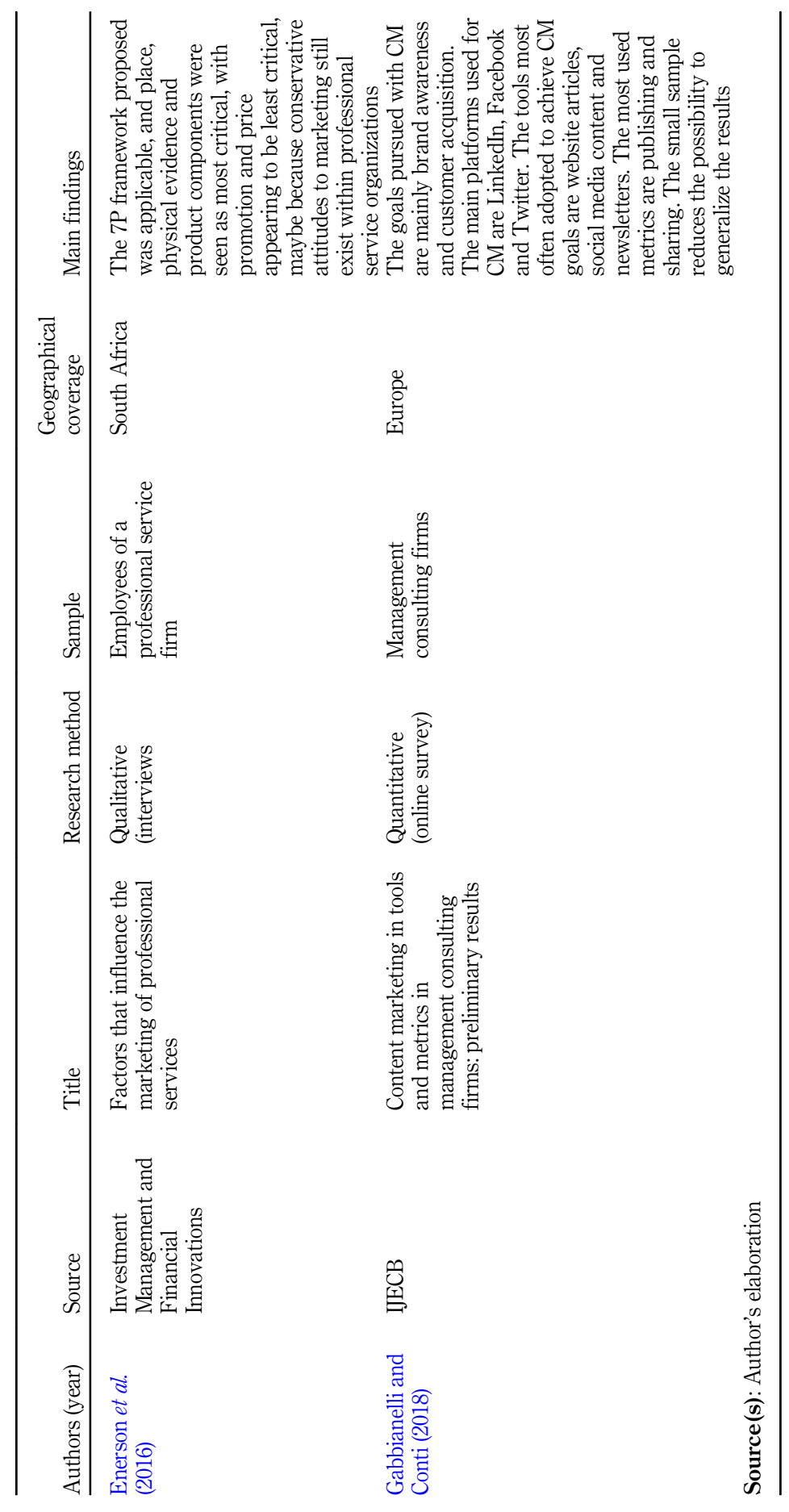

Exploring marketing practices

Table 1. 
This study contributes to fill some gaps in the literature, as adopting a quantitative research through an online survey gives insight into the marketing practices of small management consulting firms in the Italian context.

\section{The empirical research: methodology}

The study aims to answer the research questions by means of empirical analysis. A structured questionnaire was administered online and sent to Italian management consulting firms registered in the Chamber of Commerce in 2016.

The consulting companies were selected based on the activity and geographical criteria. In particular, the consulting firms selected are those that have a Nace Code [3] 70.22-Business as well as other management consultancy activities [4].

These are consulting firms located in Central Italy, namely, Marche, Abruzzo, Emilia Romagna, Lazio, Tuscany, Umbria and Veneto.

18.342 consulting companies were extracted from the archives of the Chamber of Commerce.

The questionnaire was distributed via computer-assisted web interviewing, and the respondents were contacted by e-mails. The administration of the survey was carried out in two steps. After the first round of e-mails were sent, a reminder was sent which increased the participation.

The non-response bias was assessed by verifying that early and late respondents were not significantly different, considering therefore late respondents, who answered the questionnaire only after a reminder, as those that refused to participate the first time (Armstrong and Overtyon, 1977).

The questionnaire was divided into two parts: the first part investigated the general profile of the firm, while the second part was aimed at investigating the marketing and communication processes of the consulting firm, including the acquisition and retention of customers.

To create the questionnaire items, the authors followed the literature. Afterward, in order to evaluate their validity, all the items were discussed with three management consultants all characterized for their experience in consulting.

Several control variables were also included, for example, firm size, number of customers and geographic variables (e.g. Coviello et al., 2006; Pelham, 1999) [5].

A total of 914 consulting firms fully responded to the survey, with a $5 \%$ response rate.

Considering that respondents are very busy in their everyday tasks, occupied with more urgent matters, and without forgetting that the Italian management consulting market consists for more than $80 \%$ micro firms, made up of 3 employees, the response rate is in line with the characteristics of respondents.

By applying the Brasini et al. (2002) formula [1], the number of questionnaires that had to be administered to have statistically significant results was 376 . Hence, our sample can be considered statistically significant, at least, at the time of data collecting:

$$
n=\frac{Z^{2} a / 2 N}{4(N-1) \theta^{2}+Z^{2} a / 2}=\frac{1.96^{2} \times 18342}{4(18342-1) \times 0.05^{2}+1.96^{2}}=376.30=376
$$

where:

$n=$ sample size

$Z^{2} \mathrm{a} / 2=$ confidence level $(=1.96$ : computed using tables of the standard normal distribution)

$N=$ population size

$\theta=$ margin of error (it has been set at $5 \%$ ). 
Data were processed using the SPSS software. For the purpose of the study, the consultancy firms are divided into three classes of employees: micro (less than 3), small (between 3 and 9 ) and medium-large (10 and more); while customers management consulting firms are divided into six classes: up to 25 customers, 26-50, 51-75, 76-100, 101-150 and more than 150 customers.

\section{Results}

The sample includes 914 management consulting firms which are located (Table 2) mainly in Emilia-Romagna (23\%), Veneto (20\%), Lazio (19\%) and Tuscany $(17 \%)$.

In terms of employees, $78 \%$ of the sample includes firms having less than 3 employees, in line with the national trend (Confindustria Assoconsult, 2019), where the management consulting market is primary featured by micro firms with less than 9 employees $(96 \%)$.

Considering the number of customers, most of the management consulting firms have 25 clients.

In all, $53 \%$ of management consulting firms develop and implement marketing and communication activities for their business. This happens mostly for consultancy firms with 10 and more employees ( $72 \%$ ), elthough there is a significant commitment (more than $50 \%$ ) also in smaller consulting companies. The same trend is seen when considering the number of customers: management consulting firms with more customers invest more than those with less customers. In addition, $80 \%$ of consulting companies carry out marketing activities before or without planning them.

There is also a statistically significant association between the dimension of the firm and the carrying out of marketing and communication activities (chi-square $=7.439$, Sig. $=0.024)[6]$.

Considering the number of customers, a chi-square test of independence shows that there is a significant difference between the number of customers and the carrying out of marketing and communication activities (chi-square $=13.140$; Sig. $=0.022$ ).

\begin{tabular}{lll}
\hline Region & Frequency & Percentage \\
\hline Abruzzo & 52 & $6 \%$ \\
Emilia Romagna & 210 & $23 \%$ \\
Lazio & 176 & $19 \%$ \\
Marche & 103 & $11 \%$ \\
Toscana & 157 & $17 \%$ \\
Umbria & 38 & $4 \%$ \\
Veneto & 178 & $20 \%$ \\
Overall sample & 914 & $100 \%$ \\
Number of employees & Frequency & Percentage \\
Less than 3 & 709 & $78 \%$ \\
$3-9$ & 162 & $18 \%$ \\
10 and more & 43 & $4 \%$ \\
Overall sample & 914 & $100 \%$ \\
Number of customers & Frequency & Percentage \\
Till 25 & 543 & $59 \%$ \\
$26-50$ & 164 & $18 \%$ \\
51-75 & 63 & $7 \%$ \\
$76-100$ & 47 & $5 \%$ \\
$101-150$ & 36 & $4 \%$ \\
More than 150 & 61 & $7 \%$ \\
Overall sample & 914 & $100 \%$
\end{tabular}

Source(s): Author's elaboration
Exploring marketing practices 
Consultancy companies that do not carry out marketing activities ( $47 \%$ of respondents) adopt this approach mainly because they have no time (49\%), they do not have dedicated human resources $(31 \%)$ and they consider it a useless activity (24\%). Other reasons are marketing activities are expensive $(11 \%)$ and because they cannot find anyone to advise them professionally $(9 \%)$.

However, most consulting firms (62\% of respondents) already carry out a business communication activity as it is an important part of marketing activities.

At a dimensional level, companies with 10 and more employees invest more in communicating their business compared to those of smaller size.

The chi-square test of independence shows that there is a statistically significant association between the size of management consulting firms and the communication activities (chi-square $=7.373$, Sig. $=0.025$ ) as well as between the number of customers of management consulting firms and the communication activities (chi-square $=15.025$, Sig. $=0.010)$

The main communication tools used by management consulting firms are (Table 3) the website and social media $(72 \%)$, brochures and depliants $(50 \%)$ and participation in conferences as speakers and organization of events (45\%). Videos, blogs and online communities are the least used promotional activities.

The size of the consulting companies has an impact on the business communication activities, confirmed by the chi-square test, which shows that there is a statistically significant association (Sig. $<0.05$ ) with publications, brochure and depliants, website and social network, events, newsletters and videos. The chi-square test confirms that the number of clients have an impact on communication activities, and, in particular, brochure and depliants, website and social media and newsletters (Sig. <0.005).

The online presence of consultancy companies is mainly based on the website $(65 \%)$, on LinkedIn profile (47\%) and on a Facebook page (34\%); also Google plus and Twitter channels are used, although in a lesser way (Table 4). The other channels in which consulting companies are present areInstagram and YouTube (2\% of respondents). However, it is noteworthy that $24 \%$ of consultancy companies are not present on the network, and $27 \%$ are companies with 2 employees.

In terms of firm size, almost all of the larger consulting companies have a website, while smaller companies seem to be more likely to be on LinkedIn than on Facebook.

The chi-square test indicates a significant association between the firm size and the online presence through the website, Facebook, Google plus and Twitter. There is also a statistically significant interconnection both in terms of number of employees and number of customers and the management consulting firms that are not online. Concerning the number of customers, the chi-square test shows a statistically significant association with the usage of the website and Facebook.

Social networks are used by consultancy firms to develop relationships $(69 \%)$, to promote their skills and services (68\%) as well as to acquire information on topics of interest (Table 5).

At dimensional level, there is a significant association with the promotion of skills and services, the recruitment and selection of personnel and the development of relationships.

Micro-sized consulting service firms use social networks mainly to develop relationships, while larger consulting firms aim to promote their skills. Considering the number of customers, there is a statistically significant association with the promotion of skills and the recruitment and selection of personnel (Sig. <0.005).

Concerning the relationship with customers, there are few consulting companies (30\%) that periodically carry out marketing research in order to identify their potential clients; these consulting firms are mainly the largest one.

With regard to the methods for acquiring customers by consultancy companies, the survey highlights that, in addition to word-of-mouth, respondents use e-mail communications 
TQM

Table 4.

Online presence of management consulting firms

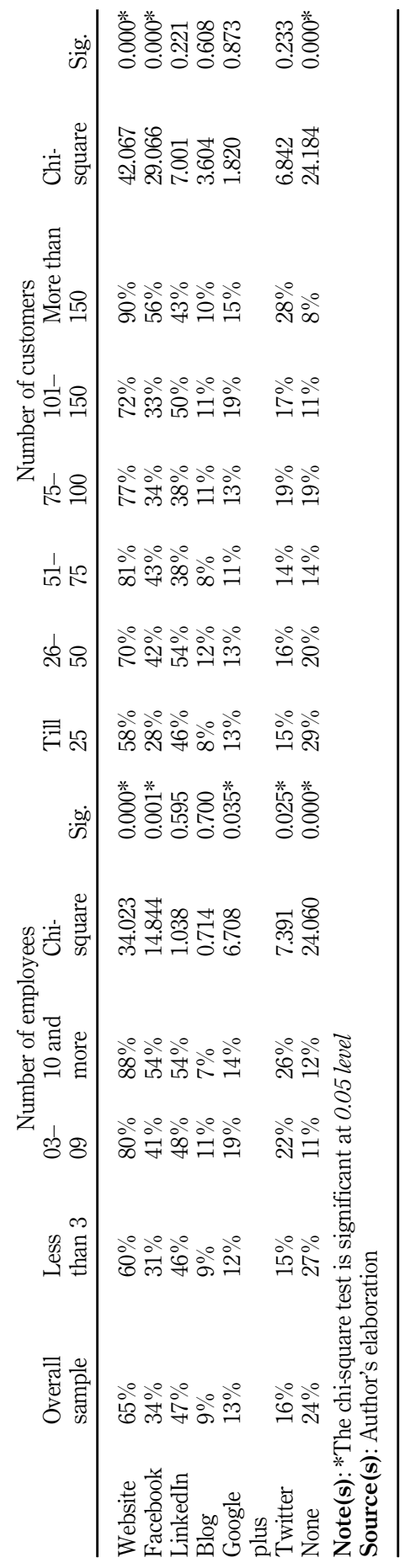


(52\%), telephone contacts $(44 \%)$ and organize events on issues of interest to potential customers $(31 \%)$.

(Table 6). However, it is interesting to note that $29 \%$ of management consulting firms focus exclusively on word-of-mouth to acquire new customers.

In terms of dimensions, a chi-square test shows that there is a statistically significant association with the online advertising, the customer request via website, the organization of events, the usage of social networks and the word-of-mouth (Sig. <0.05)

In addition, it emerges that the small consultancy firms mostly focus on word-of-mouth, while the larger service companies invest more on online means of communication.

The number of customers has an impact on the methods for acquiring new customers, confirmed by the chi-square test, as it emerges that there is a statistically significant association with the all methods considered in the survey (Sig. <0.005).

In all, $67 \%$ of management consulting firms investigated implement a set of activities aimed to retain customers and develop customer loyalty activities: organizing meeting with their customers individually for updates (70\%), making regular phone calls $(59 \%)$ and sending periodic newsletters as well as inviting them to events (38\%) (Table 7).

In terms of size, the chi-square analysis shows that there is a significant association between the dimension of management consulting firms and periodic newsletters, news on the site, invitation to events and meetings with group of clients (Sig. <0.05).

Also in terms of number of customers, there is a statistically significant association with periodic newsletters, periodic calls, news on the site, invitation to events and meeting with group of clients (Sig. $<0.005)$.

\section{Discussion of results}

The survey contributes to understanding the everyday marketing practice of management consulting firms, highlighting the level of adoption and the management of the relationship with customers.

As a matter of fact, the study contributes not only to the literature debate but also to fill some gaps in the literature (Barr and McNeilly, 2003; Enerson et al., 2016; Cerruti et al., 2019). Firstly, the study shows what management consulting firms are actually doing. Secondly, it adopts a quantitative research method through an online survey; thirdly, it considers small management consulting firms. Lastly, the study gives insights on the marketing practices of management consulting firms in the Italian context.

As it emerges in the literature, marketing activities are pretty simple, and yet management consulting firms have slowly and cautiously incorporated marketing into their strategic plans. The first research question was a preliminary one, aimed at exploring if management consulting firms consider marketing as an activity that needs to be carried out and to understand the reasons why they do not deal with it.

The research highlights that consulting firms that carry out marketing and communication activities represent $53 \%$ of the sample, many of them with a previous planification phase.

However, there are still service firms that do not carry out marketing activities because of the lack of time and of dedicated human resources; as also, it is considered a useless activity, confirming in the previous study analysis (Sweeney et al., 2011).

The second research question, more significant, wanted to investigate an activity that cannot be avoided in the service industry, which is the communication activity.

Consulting firms carry out communication activities through websites and social networks, brochures and the participation of consultants in conferences as a speaker or an expert. The largest and most structured firms, both in terms of employees and number of customers, use techniques that require more time, skills and resources such as the making of videos, publications and the organization of events. 
TQM

Table 7.

Methods of customer loyalty

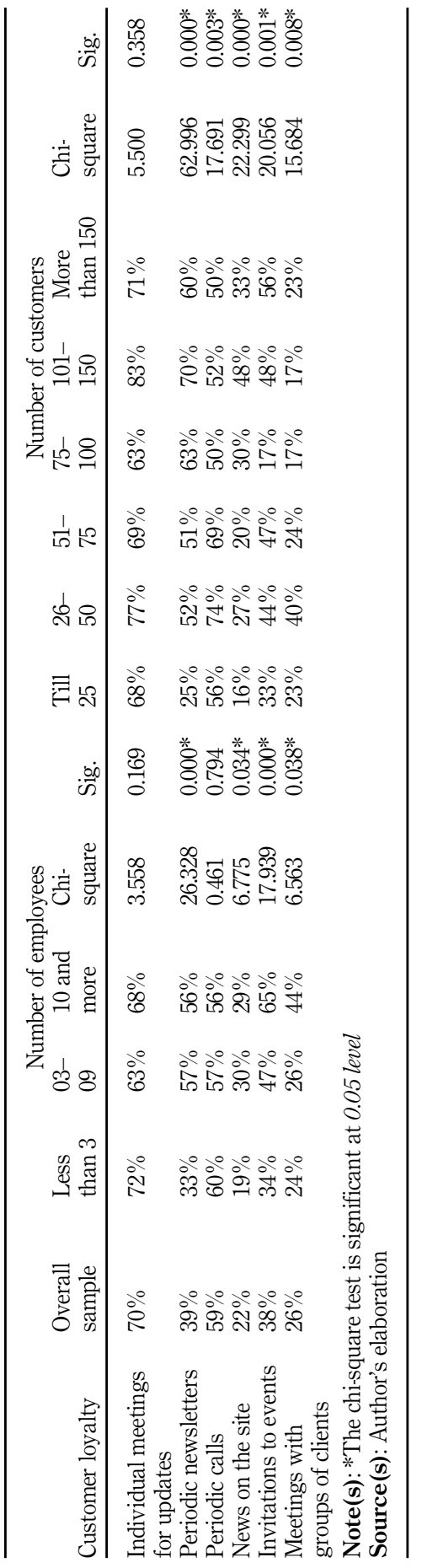


Also, according to Baaji (2014), participating in professional and social activities and joining network organizations are ways to increase the visibility and to promote the services of management consulting firms.

In the empirical survey, it emerges that consulting firms communicate their value proposition in many ways, through both online and offline communication channels.

Regarding the presence on the web, small consulting firms use the website and the Facebook and the LinkedIn page in order to promote the skills of professionals and their services as well as to develop new customer relationships.

In order to retain customers, small service companies organize individual meetings for updates (for example, follow-up visits to former clients in order to identify new selling opportunities), send newsletters and carry out phone calls, while larger ones, in addition to the above processes, invite customers to specific events.

The practice of individual meeting with customers may depend on the fact that many small businesses exploit the advantage of local proximity with clients and therefore leverage on this source to compete. Management consulting firms with more clients mainly organize individual meeting for updates and send periodic newsletters in order to retain customers.

However, the survey highlights the scarce presence of internal human resources dedicated to marketing processes, which indicates that consulting firms are more focused on processes of production and provision of services than on communication and sales processes.

As a part of the marketing activity, management consulting firms develop and implement processes in order to build and maintain relationships with clients.

Concerning the acquisition of new customers, consultancy firms do not periodically carry out market research in order to identify potential customers. This aspect is particularly accentuated in smaller companies, and it could be because of the lack of resources due to the small size of firms.

This means that in smaller consulting firms, there are no strategic approaches to customer research. However, the management consulting firms acquire new customer through both proactive and reactive approaches. In the first case, companies organize or participate in events in which consultants act as experts or speakers. In the second case, consultancy companies simply answer to contacts via email or telephone requested by potential customers.

In conclusion, as commonly underlined by the literature (Maister, 1982), management consulting is based mostly on human relationships, where relationship building, teamwork and close collaboration are key factors for value creating, together with mutual influence in a joint atmosphere between the supplier and the customer.

From empirical evidence, it emerges that there is a strong customer relationship orientation of small consulting firms that is reflected in relational marketing practice. Despite managerial principles and methodologies being neglected, efforts are made to pursue objectives of creating value for the market and for the company by developing and retaining customer relationships. In other words, the scarcity of resources of small consulting firms inhibits the implementation of professionalized marketing practices, but it does not obscure the basic approach of the companies which, in order to survive, must be necessarily and authentically customer-oriented. In this sense, we can state that small consulting firms adopt "partial relationship marketing" approaches focused on the customer, but lack in managerial activities and in systematic use of the marketing approach, in a context of poorly formalized and structured strategies, typical of small firms (Pencarelli and, Cioppi, 2009).

Reading these results with a value-creation perspective highlights the relevance of communication in the value-delivery processes (through teamwork, for example). The characteristic of the management consulting service is that the value is contextualized and durable. This means that the client should be able to use the consulting toolloutput also after

\section{Exploring marketing practices}


the end of the consulting process itself. In this context, the quality of the consulting service delivered to the customer is extremely important.

When consultancy companies intend to communicate the quality of services and their attention to the customer, they must highlight not only the "what" (the package of services offered) but also the "how" of the overall value proposition (accessibility, customer role, interaction).

All these aspects are useful to improve the customer experience and consequently the level of the customer engagement.

In consulting services, the value offer has a highly experiential content due to the customer-consultant journey that is highly interactive. The role of the client is usually active, deeply involved in all senses and plays a critical role in a variety of co-creation experiences through heterogeneous and frequent interactions with consultant suppliers.

\section{Conclusion and managerial implication}

In the economic and social context, professional services are undergoing profound changes determined mainly from the globalization of professional and consulting services and the digital revolution or the advent of the Internet and new technologies.

After an overview of the main studies related to marketing processes in consultancy companies, the paper shows the adoption of marketing and communication tools in small Italian management consulting firms. The study contributes to the literature debate because it deepens the knowledge about small management consulting firms and their marketing and communication activities. The main purpose was to understand if management consulting firms carry out marketing and communication activities and how consulting firms build and maintain relationship with customers.

In addition, the study contributes to the literature debate through an empirical research. The work, through a quantitative method (online questionnaire), has investigated the Italian context, focusing on small management consulting firms.

Our research suggests that service firms neither have a systematic use of marketing processes nor a holistic and strategic perspective of the marketing, but they practice it anyway.

The article provides some managerial implications that could be particularly useful for service providers with high knowledge content, such as to adopt a systematic and strategic approach to communication. In the current digital era, another important managerial implication refers to the opportunity to develop a complete and integrated digital communication strategy, as well as to rethink the consulting business model.

As a matter of fact, service firms everyday face relevant changes that affect their business. The most dominant challenge for consulting firms is to manage digital media that affect the ability to interact with customers in a new manner. Another important challenge refers to the increasing access to data and insights and the ability to reach new customer segments. These digital changes are considered to be much more important than changes such as the entry of new competitors (Leeflang et al., 2014).

With the advent of new digital technologies and changes in competitive dynamics, small consultancy firms are faced with new challenges to create and develop customer relationships.

To this proposal, it could be relevant, for example, to organize events on topics of major interest both through digital platforms (e.g. webinars) and through the physical presence of participants. Events could be preferably carried out in collaboration with organizations, trade associations or other management consulting firms that allow to develop cross-channel relationships and to get in contact with customers. In fact, participating in events, making requests via e-mail and the website, together with the word-of-mouth, are ways that firms 
prefer to get in touch with consultants (Gabbianelli, 2019). In a value co-creation perspective with customers, small management consultancy firms should plan, create, communicate (two-way communication between the company and the clients) and deliver value to customers, also providing digital experiential platforms and artifacts which can be properly used by customers to co-create their personal experiential value.

Furthermore, to overcome the limit of the small dimension, it may be useful for Italian consulting firms to develop aggregation processes or enter into project collaboration, creating business networks, thanks to new legal instruments such as the network contract.

The advantages of operating on the network are to have more resources to invest in marketing processes, to improve of the consulting service delivery and to practice collective pricing policies.

Thanks to the collaborative and network approach, small consultancy companies could create a digital platform with which to aggregate complementary components necessary to create, communicate and deliver an offer of consultancy value to customers, enabling them to carry out co-creation processes of value.

All consulting firms need to use marketing processes to maintain relationships with their clients and build new ones. Strategic marketing issues concern a better understanding of wants and needs of customers (both current and potential), in order to design, create, communicate and deliver value propositions tailored to customers, together with building, maintaining and improving relationship with them.

These strategies, focused on the customer, could be implemented through different marketing tactics.

Management consulting firms could invest more on Internet marketing activities, starting from being on the Internet (i.e. website) and being more active on the social network in order to better understand the customer needs using digital data analysis, user-generated data, big data or ethnographic researches on the profile of buyers (such as content analysis and sentiment analysis). The use of the Internet could also facilitate small consultancy companies in carrying out market surveys with relatively low costs and times, using online surveys or focus groups and interviews carried out using digital platforms in order to capture the real needs of firms and to intercept new potential customers.

In this sense, it could be useful to carefully plan a digital marketing and communication strategy, especially for smaller management consulting firms, that goes beyond the mere publication and sharing of contents (Gabbianelli and Conti, 2018).

In short, the Internet could help to evolve the market communication approach of professional services firms.

However, it should be noted that all these practical implications are a sort of auspices, a suggestion of some practices that management consulting firms could adopt considering the digital transformation era and the results of the survey.

As a matter of fact, the study allows to state that the website and the social network have an impact on the communication activity of management consulting firms, both in terms of size and in terms of number of customers. In addition, the website and Facebook have an impact on the online presence. However, the survey cannot demonstrate the impact of those practices in terms of firm performance.

In general, the study shows that small management consulting firms with more employees and more clients are those that practice more marketing and communication activities.

Nevertheless, the literature reveals a growing awareness about the positive relationship between marketing practices and SMEs' performance (Brooksbank et al., 1999; Cox et al., 1994; Gilmore, 2011; Verhees and Meulenberg, 2004).

Concerning the analysis of the peculiarities of SMEs' marketing behavior and practices and how they impact on their performance, it emerges that marketing processes in SMEs seem to be simpler, more informal and more instinctive than in larger firms (Carson, 2000;
Exploring marketing practices 
2001; Gilmore et al., 2001). With reference to marketing practices, activities and context, many studies analyze how SMEs actually act in their markets. Resnick and colleagues (2011) showed that the key marketing activities in which SMEs were involved concerned customer engagement, networking and word-of-mouth communication. Similarly, Reijonen (2010) found that SMEs' marketing was involved mainly in creating and maintaining customer relationships and increasing sales by exploiting effective communication processes (Bocconcelli et al., 2018).

E-marketing capabilities (that is the usage of the Internet and other interactive technologies to create and mediate dialogue between the firm and identified customers) represent a firm's competence in using the Internet and other information technologies to facilitate interactions with customers. These interactions provide customers with access to firm resources and information while simultaneously providing the firm information about its customers (Trainor et al., 2011).

Despite the increased interest in e-marketing, data in the literature explaining its link to business performance are limited (Tsioutsou and Vlachapoulou, 2011).

In sum, assuming that the relationship between marketing practices and SMEs' performance is positive, that the link between e-marketing and performance is scarcely described in literature and that small management consulting firms investigated in this survey practice marketing and communication, we could conclude that there could be a positive relationship between marketing practices and small management consulting firms.

However, future investigations should study further the impact of marketing and communication practices (both online and offline) on SMEs' performance (in terms of increased revenues, longer relationships with customers) together with the analysis of metrics for measuring the impact of social media on firm performance (Pencarelli and Mele, 2019).

Despite the limitation of investigating small consulting firms located only in one country and the limited sample at the center of Italy, the study provides some useful preliminary understanding into the tactical and strategic use of marketing, especially market communication activities, by management consulting firms.

Future academic works are encouraged to explore the adoption rate of the most used social media tools, the broadness of the digital networks of stakeholders (number of followers), the intensity of the communication activity (number of posts, shares) and the reactions (number of likes and shares). It could be interesting to understand not only the quality of the service but also the level of engagement of the customer - in other words, the experience quality.

Future studies could also perform a content analysis of posts and documents published on the social media together with the digital skills of consultants. This would allow an in-depth analysis of the nature and scope of the activities performed on social media by management consulting firms.

It could also be interesting to investigate the relationship between brand identity and brand image, distinguishing the management consulting firm brand, the consultant brand and the consulting product brand.

In an international context, future studies could concern the impact of the communication of a foreign management consulting firms on local customers.

\section{Notes}

1. Brands are a classic tool on which a firm's reputation rests (Brown and Dacin, 1997). Therefore, the information a brand conveys can be key to reducing uncertainty over the quality of a service and its provider (Bharadwaj et al., 1993).

2. Apart from co-creation of value, co-destruction of value can also occur in consultant-client interaction (Echeverri and Skålén, 2011), most often unintentionally. In co-destruction situations, consultantclient interaction is dysfunctional in a manner that results in a decline in either the consultants' or the 
clients' systemic well-being (Plé and Chumpitaz, 2010). Hence, consultant-client interaction can result in both positive and negative outcomes in terms of either party's well-being.

3. NACE (Nomenclature of Economic Activities) is the European classification of economic activities. NACE groups organizations according to their business activities.

4. The survey does not consider certified accountants, freelance, tax assistance centers (CAFs). The number of companies that carry out consultancy activities was based on those that make consultancy their main activity with a NACE code 70.22 .

5. The firm size and the number of customers are the only control variables considered in the analysis because the geographic variable does not have any significant association with the marketing practice of management consulting firms.

6. The Pearson chi-square test is a procedure for testing if two or more categorical variables are related. The -value tells if the test results are significant or not. There is a statistical significant association between the categorical variables when the $P$-value (labeled Sig. in tables) is less than 0.05 .

\section{References}

Alvesson, M. (1995), Management of Knowledge-Intensive Companies, Walter de Gruyter, Berlin.

Amonini, C., McColl-Kennedy, J.R., Soutar, G.N. and Sweeney, J.C. (2010), "How professional service firms compete in the market: an exploratory study", Journal of Marketing Management, Vol. 26 Nos 1-2, pp. 28-55.

Armbrüster, T. and Barchewitz, C. (2004), "Marketing Instruments of Management Consulting Firms: An Empirical Study", Academy of Management Best Conference Paper, Paper presented at the Academy of Management Conference, New Orleans.

Armstrong, J.S. and Overton, T.S. (1977), "Estimating nonresponse bias in mail surveys”, Journal of Marketing Research, Vol. 14 No. 3, pp. 396-402.

Baaji, M.G. (2014), An Introduction to Management Consultancy, Sage Pubblications, London.

Ballantyne, D. and Varey, R.J. (2008), "The service-dominant logic and the future of marketing", Journal of the Academy of Marketing Science, Vol. 36 No. 1, pp. 11-14.

Barcus, S.W. and Wilkinson, J.W. (1995), Handbook of Management Consulting Services, 2nd ed., McGraw-Hill, New York, NY.

Bocconcelli, R., Cioppi, M., Fortezza, F., Francioni, B., Pagano, A., Savelli, E. and Splendiani, S. (2018), "SMEs and marketing: a systematic literature review", International Journal of Management Reviews, Vol. 20 No. 2, pp. 227-254.

Brasini, S., Freo, M., Tassinari, F. and Tassinari, G. (2002), Statistica aziendale e analisi di mercato, Il Mulino, Bologna.

Barr, T.F. and McNeilly, K.M. (2003), "Marketing: is it still 'just advertising"? The experiences of accounting firms as a guide for other professional service firms", Journal of Services Marketing, Vol. 17 No. 7, pp. 713-729.

Bharadwaj, S.G., Varadarajan, P.R. and Fahy, J. (1993), "Sustainable competitive advantage in service industries: a conceptual model and research propositions”, Journal of Marketing, Vol. 57 No. 4, pp. 83-99.

Bolisani, E., Donò, A. and Scarso, E. (2015), "Relational marketing in knowledge-intensive business services: an analysis of the computer services sector", Knowledge Management Research and Practice, Vol. 14, pp. 319-328.

Brooksbank, R.W., Kirby, D.A., Taylor, D. and Jones-Evans, D. (1999), "Marketing in medium-sized manufacturing firms: the state-of the art in Britain 1987-1992", European Journal of Marketing, Vol. 33 Nos 1-2, pp. 103-120.

Brown, T.J. and Dacin, P.A. (1997), "The company and the product: corporate associations and consumer product responses", The Journal of Marketing, Vol. 61 No. 1, pp. 68-84. 
Buratti, N., Parola, F. and Satta, G. (2018), "Insights on the adoption of social media marketing in B2B services", The TQM Journal, Vol. 30 No. 5, pp. 490-529.

Carson, D. (2000), "Marketing in small firms", in Blois, K.J. (Ed.), The Oxford Textbook of Marketing, Oxford University Press, Oxford, pp. 570-591.

Carson, D. (2001), "The evolution of marketing in small firms", European Journal of Marketing, Vol. 19 No. 5, pp. 7-16.

Carucci, R.A. and Tetenbaum, T.J. (2000), The Value-Creating Consultant: How to Build and Sustain Lasting Client Relationships, AMACOM, New York, NY.

Cerruti, C., Tavoletti, E. and Grieco, C. (2019), "Management consulting: a review of fifty years of scholarly research", Management Research Review, Vol. 42, pp. 902-925.

Ciampi, F. (2014), "Defining management consulting and exploring its knowledge creation potential", Oxford Journal: An International Journal of Business and Economics, Vol. 5 No. 1, pp. 87-100.

Confindustria Assoconsult (2019), Osservatorio Sul Management Consulting in Italia, Rapporto 2018/2019, Assoconsult, Rome.

Coupey, E. (2001), Marketing and the Internet: Conceptual Foundations, Prentice Hall, New Jersey.

Coviello, N.E., Winklhofer, H. and Hamilton, K. (2006), "Marketing practices and performance of small service firms", Journal of Service Research, Vol. 9 August, pp. 38-58.

Cox, T., Hooley, G.J. and Lynch, J.E. (1994), "Marketing in small and medium-sized companies", in Saunders, J. (Ed.), The Marketing Initiative, Hemel Hempstead, Prentice Hall, pp. 305-323.

Crucini, C. (2002), "Knowledge management at the country level: a large consulting firm in Italy", in Engwall, L. and Kipping, M. (Eds), Management Consulting: Emergence and Dynamics of a Knowledge Industry, Oxford University Press, Oxford, pp. 109-128.

Echeverri, P. and Skålén, P. (2011), "Co-creation and co-destruction: a practice-theory based study of interactive value formation", Marketing Theory, Vol. 11 No. 3, pp. 351-373.

Ellis, B. and Mosher, J.S. (1993), "Six Ps for four characteristics: a complete positioning strategy for the professional services firm - CPA's”, Journal of Professional Services Marketing, Vol. 9 No. 1, pp. $129-45$.

Enerson, M., Mason, R.B. and Corbishley, K.M. (2016), "Factors that influence the marketing of professional services", Investment Management and Financial Innovations, Vol. 13 No. 3, pp. 118-130.

Ettenson, R. and Turner, K. (1997), "An exploratory investigation of consumer decision making for selected professional and non-professional services", The Journal of Services Marketing, Vol. 11 No. 2, pp. 91-104.

Fombrun, C. and Shanley, M. (1990), "What's in a name? Reputation building and corporate strategy", Academy of Management Journal, Vol. 33 No. 2, pp. 233-258.

Gabbianelli, L. (2019), La consulenza manageriale in Italia. Caratteristiche della domanda e sfide dell'offerta consulenziale, Cedam, Milano.

Gabbianelli, L. and Conti, E. (2018), "Content Marketing tools and metrics in consulting firms: preliminary results", International Journal of Economic Behavior, Vol. 8, pp. 81-99.

Gilmore, A. (2011), "Entrepreneurial and SME marketing", Journal of Research in Marketing and Entrepreneurship, Vol. 13 No. 2, pp. 137-145.

Gilmore, A., Carson, D. and Grant, K. (2001), "SME marketing in practice”, Marketing Intelligence and Planning, Vol. 19 No. 1, pp. 6-11.

Greiner, L.E. and Metzger, R.O. (1983), Consulting to Management, Prentice-Hall, Englewood Cliffs, NJ.

Grönroos, C. and Ravald, A. (2011), "Service as business logic: implications for value creation and marketing", Journal of Service Management, Vol. 22 No. 1, pp. 5-22.

Grönroos, C. and Voima, P. (2012), "Critical service logic: making sense of value creation and cocreation", Journal of the Academy of Marketing Science, Vol. 41 No. 2, pp. 133-150. 
Gummeson, E. and Grönroos, C. (2012), "The emergence of the new service marketing: nordic School perspectives", Journal of Service Management, Vol. 23 No. 4, pp. 479-497.

Gummesson, E. (1979), "The marketing of professional services - an organizational dilemma", European Journal of Marketing, Vol. 13 No. 5, pp. 308-18.

Exploring

marketing practices

Harris, L.C. and O’Malley, L. (2000), "Maintaining relationships: a study of the legal industry", Service Industries Journal, Vol. 20 No. 4, pp. 62-84.

Heischmidt, K., Elfrink, J. and Mays, B. (2002), "Professional accounting services”, Services Marketing Quarterly, Vol. 23 No. 3, pp. 63-72.

Heller, F. (2002), "What next? More critique of consultants, gurus and managers", in Clark, T. and Fincham, R. (Eds), Critical Consulting: New Perspectives on the Management Advice Industry, Blackwell Publishers Malden, MA, pp. 260-270.

Herbig, P.A. and Milewicz, J.C. (1993), "Market signaling in the professional services", Journal of Professional Services Marketing, Vol. 8 No. 2, pp. 65-80.

Huotari, L., Ulkuniemi, P., Saraniemi, S. and Mäläskä, M. (2015), "Analysis of content creation in social media by B2B companies", Journal of Business and Industrial Marketing, Vol. 30 No. 6, pp. 761-770.

Jaafar, M., Aziz, A.R.A. and Wai, A.S.W. (2008), "Marketing practices of professional engineering consulting firms: implement or not to implement?", Journal of Civil Engineering and Management, Vol. 14 No. 3, pp. 199-206.

Karam, A.H. (2003), "Marketing and architects in South Africa", Engineering Construction and Architectural Management, Vol. 10 No. 6, pp. 402-412.

Kass, E.E. and Weidner, C.K. (2002), "Toward a theory of management consulting: a proposed model and its implications", in Buono, A.F. (Ed.), Developing Knowledge and Value in Management Consulting, Information Age Publishing, Greenwich, pp. 169-207.

Kotler, P. and Connor, R.A. (1977), "Marketing professional services", Journal of Marketing, Vol. 41 No. 1, pp. 71-76.

Kotler, P., Hayes, T. and Bloom, P.N. (2002), Marketing Professional Services, Prentice-Hall, Parasmus, NJ.

Kubr, M. (2002), Management Consulting: A Guide to the Profession, 4th ed., International Labour Office Geneva, Switzerland.

Lambert, D. and Enz, M. (2012), "Managing and measuring value co-creation in business-to-business relationships", Journal of Marketing Management, Vol. 28 Nos 13-14, pp. 1588-1625.

Langrosen, S. (2005), "Effects of the internet on the marketing communication of service companies", Journal of Services Marketing, Vol. 19 No. 2, pp. 63-69.

Leeflang, P.S.H., Verhoef, P.C., Dahlström, P. and Freundt, T. (2014), "Challenges and solutions for marketing in a digital era", European Management Journal, Vol. 32, pp. 1-12.

Low, S.P., Shang Gao, S. and Mohdari, M.M. (2016), "Marketing importance and marketing performance measurement of architecture firms in Singapore: an exploratory study", Construction Management and Economics, Vol. 34 No. 11, pp. 739-750.

Macintosh, G. (2009), “The role of rapport in professional services: antecedents and outcomes”, Journal of Services Marketing, Vol. 23 No. 2, pp. 70-78.

Maister, D.H. (1982), "Balancing the professional service firm", Sloan Management Review, Vol. 24 No. 1, pp. 15-29.

Mathur, L.K., Mathur, I. and Gleason, K.C. (1998), "Services advertising and providing services on the Internet”, Journal of Services Marketing, Vol. 12 No. 5, pp. 334-347.

Mayzlin, D. and Yoganarasinhan, H. (2012), "Link to success: how blogs build an audience by promoting rivals", Management Science, Vol. 58 No. 9, pp. 1651-1668. 
McColl-Kennedy, J.R., Sweeney, J.C., Geoffrey, N. and Amonini, C. (2008), "Professional service firms are relationship marketers: but does size matter?", Australasian Marketing Journal, Vol. 16 No. 1, pp. 30-47.

Miles, I. (1993), "Services in the new industrial economy", Futures, July-August 1993, Vol. 25 No. 6, pp. 653-672.

Muller, E. and Doloreux, D. (2009), "What we should know about knowledge-intensive business services", Technology in Society, Vol. 31 No. 1, pp. 64-72.

Muller, E. and Zenker, A. (2001), "Business services as actors of knowledge transformation: the role of KIBS in regional and national innovation systems", Research Policy, Vol. 30 No. 9, pp. 1501-1516.

Nagdeman, J. (2009), The Professionals Guide to Financial Services Marketing, Wiley, Hoboken.

Onishi, H. and Manchanda, P. (2012), "Marketing activity, blogging and sales", International Journal of Research in Marketing, Vol. 29 No. 3, pp. 221-234.

Pelham, A.M. (1999), "Influence of environment, strategy and market orientation on performance in small manufacturing firms", Journal of Business Research, Vol. 45, pp. 33-46.

Pencarelli, T. and Cioppi, M. (2009), "La comunicazione di marketing nelle piccole imprese: alcune evidenze empiriche”, Piccola Impresa/Small Business, Vol. 1, pp. 71-98.

Pencarelli, T. and Forlani, F. (2018), "Marketing in an experiential perspective: from 'goods and service logic' to 'experience logic", in Pencarelli, T. and Forlani, F. (Eds), The Experience Logic as a New Perspective for Marketing Management, Springer, Cham, pp. 43-67.

Pencarelli, T. and Mele, M.G. (2019), “A systematic literature review on social media metrics”, Mercati and Competitività, Vol. 1, pp. 15-38.

Plé, L. and Chumpitaz, R. (2010), "Not always co-creation: introducing interactional co-destruction of value in service-dominant logic", Journal of Services Marketing, Vol. 24 No. 6, pp. 430-437.

Prahalad, C.K. and Ramaswamy, V. (2004), The Future of Competition: Co-creating Unique Value with Customers, Harvard Business School Press, Boston, MA.

Ramsey, E. and McCole, P. (2005), "E-business in professional SMEs: the case of New Zealand", Journal of Small Business and Enterprise Development, Vol. 12 No. 4, pp. 528-544.

Reid, M. (2008), "Contemporary marketing in professional services", Journal of Services Marketing, Vol. 22 No. 5, pp. 374-84.

Reijonen, H. (2010), "Do all SMEs practise same kind of marketing?", Journal of Small Business and Enterprise Development, Vol. 17 No. 2, pp. 279-293.

Roxas, M.L., Peek, L., Peek, G. and Hagemann, T. (2000), "A preliminary evaluation of professional accounting services: direct marketing on the Internet", Journal of Service Marketing, Vol. 14 No. 7 , pp. 595-606.

Sarvary, M. (1999), "Knowledge management and competition in the consulting industry", California Management Review, Vol. 41 No. 2, pp. 95-107.

Sharma, N. and Patterson, P.G. (1999), "The impact of communication effectiveness and service quality on relationship commitment in consumer and professional services", Journal of Services Marketing, Vol. 13 No. 2, pp. 151-170.

Sieg, J.H., Fischer, A., Wallin, M.W. and von Krogh, G. (2012), "Proactive diagnosis: how professional service firms sustain client dialogue", Journal of Service Management, Vol. 23 No. 2, pp. 253-278.

Steele, F. (1975), Consulting for Organizational Change, University of Massachusetts Press, Amherst, MA.

Svensson, P. (2010), Doing Value: Exclusion and Inclusion in Management Consultant-Client Interactions, Lund Institute of Economic Research Working Paper Series 2010/3. 
Sweeney, J.C., Soutar, G.N. and McColl-Kennedy, J.R. (2011), "The marketing practices - performance relationship in professional service firms", Journal of Service Management, Vol. 22 No. 3, pp. 292-316.

Trainor, K.J., Rapp, A., Beitelspacher, L.S. and Schillewaert, N. (2011), "Integrating information technology and marketing: an examination of the drivers and outcomes of e-marketing capability", Industrial Marketing Management, Vol. 40 No. 1, pp. 162-174.

Treem, J.W. (2012), "Communicating expertise: knowledge performances in professional-service firms", Communication Monographs, Vol. 79 No. 1, pp. 23-47.

Trusov, M., Bucklin, R.E. and Pauwels, K. (2009), "Effects of word-of-mouth versus traditional marketing: findings from an internet social networking site", Journal of Marketing, Vol. 73 No. 5, pp. 90-102.

Tsioutsou, R.H. and Vlachapoulou, M. (2011), "Understanding the effect of market orientation and e-marketing on service performance", Marketing Intelligence and Planning, Vol. 29 No. 2, pp. 141-155.

Vargo, S.L. and Lusch, R.F. (2004), "Evolving to a new dominant logic for marketing", Journal of Marketing, Vol. 68 No. 1, pp. 1-17.

Vargo, S.L. and Lusch, R.F. (2008), "Service-dominant logic: continuing the evolution”, Journal of the Academy of Marketing Science, Vol. 36 No. 1, pp. 1-10.

Verhees, F.J.H.M. and Meulenberg, M.T.G. (2004), "Market orientation, innovativeness, product innovation, and performance in small firms", Journal of Small Business Management, Vol. 42 No. 2, pp. 134-154.

von Nordenflycht, A. (2010), "What is a professional service firm? Towards a theory and taxonomy of knowledge intensive firms", Academy of Management Review, Vol. 35 No. 1, pp. 155-174.

Werr, A. (2002), "The internal creation of consulting knowledge: a question of structuring experience", Engwallans Kipping, L.M. (Ed.), Management consulting: Emergence and dynamics of a knowledge industry, Oxford University Press, Oxford.

Whittle, A. (2006), "The paradoxical repertoires of management consultancy", Journal of Organizational Change Management, Vol. 19 No. 4, pp. 424-436.

Woo, K.M. and Leelapanyalert, K.M. (2014), "Client relationship marketing practices: an exploratory study of the legal industry", Journal of Relationship Marketing, Vol. 13 No. 4, pp. 286-317.

\section{Corresponding author}

Linda Gabbianelli can be contacted at: linda.gabbianelli@uniurb.it

\section{Exploring marketing practices}

